\title{
No Effect of Serotoninergic Gene Variants on Response to Interpersonal Counseling and Antidepressants in Major Depression
}

\author{
Alessandro Serretti ${ }^{1}$, Chiara Fabbri ${ }^{1}$, Silvia Pellegrini ${ }^{2}$, Stefano Porcelli ${ }^{1}$, Pierluigi Politi ${ }^{3}$, \\ Silvio Bellino ${ }^{4}$, Marco Menchetti ${ }^{1}$, Veronica Mariotti ${ }^{2}$, Cristina Demi ${ }^{2}$, Valentina Martinelli ${ }^{3}$, \\ Marco Cappucciati ${ }^{3}$, Paola Bozzatello ${ }^{4}$, Elena Brignolo ${ }^{4}$, Paolo Brambilla ${ }^{5}$, Chi-Un Pae ${ }^{6,7}$, \\ Matteo Balestrieri ${ }^{5}$ and Diana De Ronchi ${ }^{1}$ \\ ${ }^{1}$ Department of Biomedical and NeuroMotor Sciences, University of Bologna, Bologna, Italy \\ ${ }^{2}$ Department of Experimental Pathology, Medical Biotechnology, Epidemiology and Infectious Diseases, University of Pisa, Pisa, Italy \\ ${ }^{3}$ Department of Health Sciences, Section of Psychiatry, University of Pavia, Pavia, Italy \\ ${ }^{4}$ Neuroscience Department, Turin University, Turin, Italy \\ ${ }^{5}$ Inter-University Centre for Behavioural Neurosciences (ICBN), University of Verona, Verona and DPMSC, Section of Psychiatry, \\ University of Udine, Udine, Italy \\ ${ }^{6}$ Department of Psychiatry, Bucheon St. Mary's Hospital, The Catholic University of Korea College of Medicine, Bucheon, \\ Republic of Korea \\ ${ }^{7}$ Department of Psychiatry and Behavioral Sciences, Duke University Medical Center, Durham, NC, USA
}

Objective Gene variants within the serotonin pathway have been associated with major depressive disorder (MDD) treatment outcomes, however a possible different modulation on pharmacological or psychological treatments has never been investigated.

Methods One hundred sixty MDD patients were partially randomized to either inter-personal counseling (IPC) or antidepressants. The primary outcome was remission at week 8. Five serotonergic polymorphisms were investigated (COMT rs4680, HTR1A rs6295, HTR2A rs2224721, HTR2A rs7997012 and SLC6A4 rs421417).

Results IPC $(\mathrm{n}=43)$ and antidepressant $(\mathrm{n}=117)$ treated patients did not show any difference in remission rates at week 8 (corrected for baseline severity, age and center). None of the studied gene variants impacted on response and remission rates at week 8 neither in the IPC nor in the antidepressant group. An analysis of the whole sample showed a trend of association between rs7997012 AA genotype and a better treatment outcome.

Conclusion Our study confirms that IPC is an effective psychological intervention comparable to antidepressants in mild-moderate MDD. Polymorphisms related to the serotonin system did not exert a major effect on clinical outcomes in none of the treatment groups.

Psychiatry Investig 2013;10:180-189

Key Words Antidepressants, Psychotherapy, 5-HT, 5-HT1A receptor, 5-HT2A receptor, Serotonin transporter, COMT, Genes, Polymorphism, Major depression.

\section{INTRODUCTION}

Major depressive disorder (MDD) is the most common psy-

Received: September 27, 2012 Revised: October 22, 2012

Accepted: November 6, 2012 Available online: May 30, 2013

$\square$ Correspondence: Alessandro Serretti, MD, PhD

Department of Biomedical and NeuroMotor Sciences, University of Bologna, Viale Carlo Pepoli 5, 40123 Bologna, Italy

Tel: +39 051 6584233, Fax: +39 051 521030, E-mail: alessandro.serretti@unibo.it

(c) This is an Open Access article distributed under the terms of the Creative Commons Attribution Non-Commercial License (http://creativecommons.org/licenses/by$\mathrm{nc} / 3.0$ ) which permits unrestricted non-commercial use, distribution, and reproduction in any medium, provided the original work is properly cited. chiatric disorder (life-time prevalence: $12.8 \%$ ), and it is responsible for the great burden linked to non-fatal health outcomes. ${ }^{1}$ After the introduction of antidepressant drugs in the '50, no substantial improvement in MDD clinical management was achieved, given the still unsatisfactory response and remission rates [47 and 33\%, respectively, in the large Sequenced Treatment Alternatives to Relieve Depression (ST$\mathrm{AR}^{*} \mathrm{D}$ ) cohort]. ${ }^{2}$ Nowadays, together with the introduction of innovative antidepressant molecules, the identification of reliable predictors of treatment response for the each subject is expected in order to provide a substantial improvement of 
MDD prognosis.

Among treatment options, selective serotonin reuptake inhibitors (SSRIs) are the first line treatment and psychological interventions such as inter-personal counseling (IPC) have been suggested to have comparative efficacy and effectiveness when compared to antidepressants (response rates are from $30 \%$ to $50 \%$ regardless the choice of pharmacotherapy or psychotherapy), ${ }^{3}$ particularly in moderate MDD. Combined treatment may provide a small advantage (with effect size estimated from 0.25 to 0.35 ), even if it does not seem to persist during medium-long follow-up and not to be significant in mild MDD. ${ }^{4}$ However no clear guideline is available to choose the best treatment in each patient, even if some clinical predictors of IPC vs. antidepressant pharmacotherapy efficacy have been proposed. ${ }^{5}$ Thus, further evidence is needed to better clarify the efficacy of brief psychotherapies vs pharmacological treatments and to identify reliable predictors of clinical outcomes.

Among predictors of treatment response, genetic factors are estimated to contribute for a substantial degree to the interindividual variability. ${ }^{6}$ Given that monoamines are pivotal in antidepressant response, ${ }^{7}$ genes related to the serotoninergic system are considered among the most promising candidates. Particularly, serotonin receptors, serotonin transporter and enzymes responsible for the metabolism of monoamines are involved in the regulation of the serotoninergic neurotransmission in the CNS.

The serotonin 2A receptor (coded by HTR2A gene) is expressed in all neocortical areas, in putative interneurons, hippocampus and prefrontal cortex. ${ }^{8}$ It is down-regulated by different classes of antidepressants in parallel with the improvement of clinical symptoms ${ }^{9}$ and some interesting polymorphisms were reported within HTR2A. Particularly, rs7997012 was strongly associated with citalopram response in the STAR*D study, ${ }^{10,11}$ even if other studies obtained inconsistent findings (negative results ${ }^{12-16}$ in the opposite direction ${ }^{17}$ or association only when considering the interaction with gen$\left.\operatorname{der}^{18}\right)$. Rs 2224721 harbored by the same gene was associated with the risk of bipolar disorder ${ }^{19}$ and was one of the two best predictors of escitalopram response in the GENDEP (Genome-based Therapeutic Drugs for Depression) sample, ${ }^{14}$ suggesting it as a promising target for further investigation.

A role of the HTR1A gene in antidepressant response has also been postulated because several antidepressants desensitize raphe 5-HT1A autoreceptors, leading to an enhancement of the 5-HT neurotransmission. Moreover there is evidence that the blockade of 5-HT1A autoreceptors may accelerate antidepressant effect. ${ }^{6}$ The most promising SNP within the gene is the rs6295 $(1019 \mathrm{C} / \mathrm{G})$, since the G allele was associated with an up regulation of the expression of the receptor ${ }^{20,21}$ leading to the hypothesis that it may contrast the therapeutic effect of antidepressants through a higher number of inhibitory 5-HT1A autoreceptors. This hypothesis is supported by several pharmacogenetic studies, ${ }^{22-28}$ while some negative reports exist. ${ }^{16,29-32}$ Interestingly, an interaction with gender was reported for ${\text { rs } 6295^{33}}^{3}$ as well as for rs7997012.

The serotonin transporter gene (SLC6A4) is probably the leading candidate as predictor of antidepressant response, since it codes for one of the main target of antidepressant drugs. Polymorphic variants within the promoter have gained particular attention, since their supposed effect on gene expression regulation. ${ }^{6}$ Research efforts were mainly directed towards the study of the insertion/deletion variant (5-HTTLPR), and to a less extent, rs25531, but the need to provide a better coverage of the region recently emerged. Rs4251417 harbored by this genomic region was found in linkage disequilibrium with 5-HTTLPR ${ }^{34}$ and its possible role in antidepressant response has not been investigated yet.

Finally, the catechol-O-methyltransferase (COMT) gene codes for an intracellular enzyme with a key role in the inactivation of monoamines. Rs4680 (Val108/158Met) is a functional polymorphism which Val/Val genotype catabolizes dopamine at up four times the rate of Met/Met homozygote. ${ }^{35}$ Given the close interactions between the serotonergic and dopaminergic systems, dopamine availability in some areas of the CNS such as the frontal cortex and the nucleus accumbens was reported to modulate antidepressant response. ${ }^{6}$ Pharmacogenetic findings about rs4680 mainly confirmed it plays a role in antidepressant response, ${ }^{36-41}$ while which genotype/allele is associated with poorer outcome still remains unclear. ${ }^{6}$ A sexually dimorphic effect was reported also for this polymorphism. ${ }^{40}$

The mechanisms behind the antidepressant efficacy of psychotherapy in MDD are less known. The main hypothesis is a direct effect on cognitive processes such as dysfunctional attitudes and negative automatic thoughts, ${ }^{42}$ but the knowledge about the molecular processes involved is poor. Anyway, improvement of cognitive measures is not different between patients treated with pharmacotherapy and psychotherapy, ${ }^{43}$ suggesting that ultimately common mechanisms mediate the efficacy of both therapeutic approaches. This is also supported by the evidence of monoamines balance modification during psychotherapy, involving in particular serotonin transporter activity. ${ }^{44,45}$

Given the reported unsolved issues, the present paper aims to study the role of HTR2A rs7997012 and rs2224721, HTR1A rs6295, SLC6A4 rs4251417 and COMT rs4680 on antidepressant efficacy in a sample of $160 \mathrm{MDD}$ Italian patients, treated with IPC or antidepressants. No previous study investigated the possible effect of these polymorphism on IPC response. 


\section{METHODS}

\section{Sample}

Patients aged 18 years or older with diagnosis of MDD (according to DSM-IV TR criteria), with a score $\geq 13$ on Hamilton Depression Rating Scale (HDRS, 21-item version, in accordance to STAR*D criteria ${ }^{2}$ ), were eligible for inclusion. Any other psychiatric disorder as primary diagnosis (bipolar disorder included), comorbidity for substance abuse, cognitive impairment (Mini Mental State Evaluation <28), poor ability to participate to evaluations and current pregnancy or feeding were exclusion criteria. After a baseline assessment, eligible patients were partially randomized to a brief structured psychological intervention (IPC) or to antidepressant treatment (mainly SSRIs)(Table 1$){ }^{46}$ Patients were collected

Table 1. Clinical-demographic characteristics of the whole sample

\begin{tabular}{|c|c|}
\hline Variable & Value \\
\hline Gender (F/M) & $105 / 55$ \\
\hline Age (mean \pm SD) & $50.71 \pm 18.01$ \\
\hline $\begin{array}{l}\text { Number of previous depressive } \\
\text { episodes (mean } \pm \text { SD) }\end{array}$ & $0.89 \pm 1.32$ \\
\hline Baseline severity (HDRS) & $17.97 \pm 5.26$ \\
\hline Treatment (\%) & $\begin{array}{l}91 \text { (56.88): SSRIs } \\
18 \text { (11.25): SNRIs } \\
8 \text { (5.00): other antidepressants } \\
43 \text { (26.88): IPC }\end{array}$ \\
\hline Employment $(\%)^{\dagger}$ & $\begin{array}{l}39 \text { (31.20): employed } \\
7 \text { (5.60): housewife } \\
15 \text { (12.00): student } \\
6 \text { (4.80): unemployed } \\
32 \text { (25.60): retired } \\
26 \text { (20.80): other or unknown }\end{array}$ \\
\hline Personality disorder (SCIDII)* & $\begin{array}{l}4 \text { (3.36): cluster A } \\
19 \text { (15.97): cluster B } \\
9 \text { (7.56): cluster C } \\
5 \text { (4.20): NAS } \\
61 \text { (51.26): none } \\
21 \text { (17.65): unknown }\end{array}$ \\
\hline Education (years) (mean \pm SD) & $11.69 \pm 4.79$ \\
\hline Marital status $(\%)^{\dagger}$ & $\begin{array}{l}40 \text { (32.00): single } \\
50 \text { (40.00): } \text { married } \\
14 \text { (11.20): separated/divorced } \\
14 \text { (11.20): widowed } \\
7 \text { (5.60): unknown }\end{array}$ \\
\hline Available genotypes & 157 \\
\hline
\end{tabular}

*available for only 2 centers (Bologna and Torino), tavailable for only two centers (Bologna and Pavia). HDRS: Hamilton Depression Rating Scale 21-items, SCIDII: Structured Clinical Interview for DSM IV axis II personality disorders, NAS: non otherwise specified, IPC: interpersonal counseling, SD: standard deviation in three centers: 35 were collected at the Neuroscience Department, Turin University, 41 at the Department of Health Sciences, Section of Psychiatry, University of Pavia and 84 at the Department of Biomedical and NeuroMotor Sciences, Bologna University. All patients collected at the Institute of Psychiatry, Bologna University were treated with antidepressants and not randomized.

Patients were carefully informed about all study procedures before signing written informed consent. Ethical approval was obtained from local research ethic committees.

\section{Interpersonal counseling (IPC)}

IPC is a brief manualized psychological intervention, derived from Interpersonal Psychotherapy (IPT). IPC has been adapted and tested on patients with depressive disorders, in association with pharmacological treatment or alone. ${ }^{47-50}$ It consisted of six thirty-minute sessions, with the initial session being longer, and is focused on patients' current psychological problems and social functioning and specifically on four interpersonal problem areas: prolonged grief, interpersonal disputes, role transitions and interpersonal deficits; ${ }^{51}$ patients are helped to identify effective strategies in order to deal with their interpersonal problems. To ensure the intervention's consistency, therapists attended a 3-day teaching seminar on IPC techniques and monthly group supervisions with videotaped sessions.

\section{Evaluations}

All patients were evaluated with both structured and unstructured interviews to obtain lifetime diagnoses assigned by two independent experienced psychiatrists, on the basis also of medical records, according to DSM-IV TR criteria. Current and lifetime Axis I and II diagnoses were assessed by Mini International Neuropsychiatric Interview (MINI) and structured clinical interview for DSM-IV TR Axis II Personality disorders. Cognitive impairment was assessed by Mini Mental State Examination (MMSE) in patients older than 60. Depressive symptoms were assessed at baseline and after 8 weeks through HDRS. Interrater evaluations were satisfactory $(\mathrm{k}>0.8)$.

\section{Outcomes}

The primary outcome was remission at week 8 , defined according to standard criteria (HDRS score $\leq 7$ ). The secondary outcomes were response (at least 50\% reduction in HDRS score) and HDRS percent improvement at week 8.

\section{Genotyping}

Genomic DNA was purified from whole blood using the QIAamp DNA Blood Midi Kit (Qiagen, CA, USA), according 
to the manufacturer's protocol. Rs7997012 and rs2224721 (HTR2A, chr 5q11.2-q13), rs6295 (HTR1A, chr 5q11.2-q13), rs4251417 (SLC6A4, chr 17q11.2) and rs4680 (COMT, chr 22q11.21) were genotyped by High Resolution Melting (HRM) -PCR. All the experiments were performed by the Rotor Gene Q instrument (Qiagen, CA, USA), using the Type-it HRM PCR Kit (Qiagen, CA, USA). The following primers were used for PCR amplifications:

F-5'-GAACGCTGAGTTGATGTAAT-3' and R-5'-CCACC TTCCAAGAATCCT-3' (rs7997012), F-5'-ACCCAATCACTAAATCCT-3' and R-5'-GGAAACTAGACCAGTAAAG-3' (rs2224721), F-5'-GCGAGAACGGAGGTAGCTTT-3' and R-5'-GGTCAGTCTCCCAATTATTGCT-3' (rs6295), F-5'CTGAGGACTCCTGAGAAC-3' and R-5'-CAGAGAGGGTAGAAAATGTG-3' (rs4251417), F-5'-CAGCGGATGGTGGATTTC-3' and R-5'-TTCCAGGTCTGACAACGG-3' (rs4680), all designed by Beacon Designer v. 7.9 (PREMIER Biosoft, CA, USA). After an initial step of enzyme activation at $95^{\circ} \mathrm{C}$ for $5 \mathrm{~min}$, PCRs were carried out by 40 cycles as follows: denaturation at $95^{\circ} \mathrm{C}$ for $10 \mathrm{sec}$ and annealing at $60^{\circ} \mathrm{C}$ for $30 \mathrm{sec}\left(56^{\circ} \mathrm{C}\right.$ for rs 2224721$)$. The HRM analysis was performed with a temperature resolution of $0.1^{\circ} \mathrm{C}$ and a temperature range between $70^{\circ} \mathrm{C}$ and $85^{\circ} \mathrm{C}$. Data collection and genotype calls were obtained by the Rotor-Gene 6000 series software v. 1.7 (Qiagen, CA, USA) using as reference genotypes DNA samples sequenced by the ABI Prism ${ }^{\circledR} 310$ Genetic Analyzer (Applied Biosystems, CA, USA).

\section{Statistical analysis}

Chi-squared test, Fisher's exact test and student's t test were used as appropriate for comparing baseline characteristics among treatment groups (Table 2). The effect of genotypes and alleles on response and remission rates was estimated through Pearson's chi-squared tests. In order to account for the confounding effect of recruitment site and baseline HDRS impact on response and remission in the IPC group (Table 2), one-way ANOVA was used within a linear regression model to study the effect of genotypes and alleles on clinical outcomes adjusting for the reported variables. Given that a gender-dimorphic effect has been previously reported for three of the studied polymorphisms (see Introduction), the possible interaction allele $\mathrm{x}$ gender was also tested. Only results obtained in the completers group (Table 2) were reported since the presence of only two time points of evaluation did not allow a reliable application of the last observation carried forward (LOCF) method. Analysis were carried out both in the two treatment arms separately and in the whole sample, since similar mechanisms are supposed to mediate the antidepressant effect of both treatments. ${ }^{44,45}$ The level of significance was conservatively set to 0.05 . R software was used for the analysis (cran.r-project.org/). Genotype frequencies were evaluated for Hardy-Weinberg equilibrium using Haploview 4.2. Our sample setting alpha value to 0.05 two tailed provides a power of 0.80 to observe for the whole sample a difference between two variants with effect size $\mathrm{d}=0.26$, which corresponds to a difference of (at least) 1.5 points in the final HDRS and to an explained variance of $2.2 \%$.

\section{RESULTS}

The studied polymorphisms did not show any deviation from Hardy-Weinberg equilibrium (COMT rs4680: $\mathrm{p}=0.14$; HTR1A rs6295: $\mathrm{p}=0.25$; HTR2A rs2224721: $\mathrm{p}=1$; HTR2A rs7997012: $\mathrm{p}=0.62$; SLC6A4 rs4251417: $\mathrm{p}=0.98$ ).

Clinical-demographic characteristics of the sample were reported in Table 1 for the whole sample and in Table 2 for

Table 2. Clinical characteristics and outcomes at week 8 according to treatment group. Chi-squared and Fisher's exact tests were used as appropriate to test differences between the two treatment groups

\begin{tabular}{|c|c|c|c|c|}
\hline & Whole sample $(\mathrm{N}=145)$ & $\mathrm{ICP}(\mathrm{N}=42)$ & Antidepressants $(\mathrm{N}=103)$ & Statistics \\
\hline \multicolumn{5}{|l|}{ Response } \\
\hline Yes & $93(64.14 \%)$ & $26(61.90 \%)$ & $67(65.05 \%)$ & \multirow[t]{2}{*}{$\chi^{2}=0.03, d f=1, p=0.87$} \\
\hline No & $52(35.86 \%)$ & $16(38.10 \%)$ & $36(34.95 \%)$ & \\
\hline \multicolumn{5}{|l|}{ Remission } \\
\hline Yes & $91(62.76 \%)$ & $29(69.05 \%)$ & $62(60.19 \%)$ & \multirow[t]{2}{*}{$\chi^{2}=0.66, d f=1, p=0.42$} \\
\hline No & $54(37.24 \%)$ & $13(30.95 \%)$ & $41(39.81 \%)$ & \\
\hline Improvement (\%) & $54.85 \pm 28.61$ & $52.05 \pm 19.40$ & $56.01 \pm 31.53$ & $\mathrm{t}=-0.92, \mathrm{CI}=-0.13-0.046, \mathrm{p}=0.36$ \\
\hline HDRS missing at week 8 & 15 & 1 & 14 & $\mathrm{OR}=0.18, \mathrm{CI}=0.004-1.23, \mathrm{p}=0.07$ \\
\hline Baseline severity (HDRS) & $17.97 \pm 5.26$ & $16.33 \pm 4.08$ & $18.56 \pm 5.48$ & $\mathrm{t}=-2.79, \mathrm{CI}=-3.83--0.65, \mathrm{p}=0.006$ \\
\hline Age & $50.71 \pm 18.01$ & $53.24 \pm 18.15$ & $43.93 \pm 15.93$ & $\mathrm{t}=-3.15, \mathrm{CI}=-15.20--3.43, \mathrm{p}=0.002$ \\
\hline Gender (F/M) & $105 / 55$ & $25 / 18$ & $80 / 37$ & $\chi^{2}=1.43, \mathrm{df}=2, \mathrm{p}=0.49$ \\
\hline
\end{tabular}

CI: 95\% confidence interval, IPC: interpersonal counseling, HDRS: Hamilton Depression Rating Scale 21-items 
each treatment group. For 15 patients (9.38\%) HDRS was not available at week 8 (Table 2), but this group did not show any difference in age $(47.93 \pm 18.17 ; \mathrm{t}=-0.60, \mathrm{CI}=-13.85-7.75, \mathrm{p}=$ $0.56)$, gender $(\mathrm{F} / \mathrm{M}: 10 / 5$; chi2 $=1.04, \mathrm{df}=1, \mathrm{p}=0.31)$ and baseline severity $(21.47 \pm 9.52 ; \mathrm{t}=1.56, \mathrm{CI}=-1.44-9.18, \mathrm{p}=0.14)$ when compared to the 8 week-completers. Moreover, no different risk of drop-out was found between the ICP and antidepressant group, though a trend of better retention was detected in the IPC group (Table 2). No difference was also observed in response and remission rates and percent of improvement at week 8 between the two treatment groups (Table 2), also adjusting for age, baseline severity and center (response: $\mathrm{F}=0.19, \mathrm{df}=1, \mathrm{p}=0.66$; remission: $\mathrm{F}=1.15, \mathrm{df}=1, \mathrm{p}=$ 0.29; \% improvement: $\mathrm{F}=0.59, \mathrm{df}=1, \mathrm{p}=0.44)$. In the IPC group the remission rate was slightly higher than the response rate, and this was explained by a lower baseline severity in this treatment arm than the pharmacotherapy arm. Nevertheless, the difference was not so pronounced to be clinically relevant and all regression models were adjusted for baseline severity. Age, gender and presence of a personality disorder did not show any effect on outcomes in both treatment groups (Table $3)$. On the other hand, response and remission rates were influenced by baseline severity in the IPC group (Table 3 ).

\section{Serotonin-related polymorphisms}

None of the investigated polymorphisms showed to affect response and remission rates neither in the IPC nor in the an- tidepressant treated group (Table 3 and 4). One-way ANOVA confirmed no effect of genetic variants on clinical outcomes after adjusting for center and baseline severity in the IPC group (data not shown). On the other hand, in the whole sample a trend of association between rs7997012 (HTR2A) and remission was observed $\left(\chi^{2}=5.78, \mathrm{df}=2, \mathrm{p}=0.056\right)$, confirmed by one-way ANOVA adjusted for baseline severity and centre $(\mathrm{F}=2.93, \mathrm{df}=2, \mathrm{p}=0.057)$. Subjects carrying the AA genotype showed lower 8-week improvement of the HDRS score (38.74 33.89 ) compared to those carrying the GA genotype (58.13 27.91) and the GG genotype (55.67 \pm 27.33$)$.

No major gender-stratification effect was detected. However, HTR2A rs2224721 showed a trend of interaction with gender: in the IPC group males carrying the A allele showed lower HDRS improvement than those carrying the $\mathrm{C}$ allele, while this difference was not observed in females $(\mathrm{F}=6.38, \mathrm{df}=1, \mathrm{p}=$ $0.01)$. Indeed, the HDRS improvement (\%) at week 8 was $42.64 \pm 17.02$ in males carrying the A allele, while it was $52.27 \pm$ 11.81 in carriers of the $\mathrm{C}$ allele. In females instead, the improvement was similar for both alleles (C: 51.95 \pm 21.15 ; A: $55.85 \pm 27.73)$. A trend in the same direction was found in the antidepressant treated group $(\mathrm{F}=3.96, \mathrm{df}=1, \mathrm{p}=0.048)$ as well as in the whole sample $(\mathrm{F}=2.79, \mathrm{df}=1, \mathrm{p}=0.096)$.

\section{DISCUSSION}

The present study investigated the efficacy of a brief struc-

Table 3. Distribution of clinical variables according to response and remission status, for each treatment group

\begin{tabular}{|c|c|c|c|c|c|c|}
\hline & Responders & Non responders & Stat & Remitters & Non remitters & Stat \\
\hline \multicolumn{7}{|l|}{ IPC } \\
\hline Age & $40.96 \pm 14.90$ & $49.13 \pm 17.15$ & $\begin{array}{c}\mathrm{t}=-1.57, \mathrm{CI}=-18.78-2.46 \\
\mathrm{p}=0.13\end{array}$ & $44.68 \pm 15.66$ & $42.69 \pm 17.61$ & $\begin{aligned} \mathrm{t}=0.35, \mathrm{CI} & =-9.83-13.82, \\
\mathrm{p} & =0.73\end{aligned}$ \\
\hline Gender (F/M) & $15 / 11$ & $10 / 6$ & $\begin{array}{c}\chi^{2}=2 \mathrm{e}-04, \mathrm{df}=1 \\
\mathrm{p}=0.99\end{array}$ & $17 / 12$ & $8 / 5$ & $\begin{array}{c}\chi^{2}=0.03, \mathrm{df}=1 \\
\mathrm{p}=0.87\end{array}$ \\
\hline $\begin{array}{l}\text { Baseline severity } \\
\text { (HDRS) }\end{array}$ & $17.54 \pm 3.75$ & $14.56 \pm 4.07$ & $\begin{array}{c}\mathrm{t}=2.37, \mathrm{CI}=0.41-5.54, \\
\mathrm{p}=0.024\end{array}$ & $15.34 \pm 3.12$ & $18.77 \pm 5.09$ & $\begin{array}{c}\mathrm{t}=-2.25, \mathrm{CI}=-6.65-0.20 \\
\mathrm{p}=0.039\end{array}$ \\
\hline $\begin{array}{l}\text { Personality disorder } \\
\text { (yes/no)* }\end{array}$ & $4 / 8$ & $4 / 4$ & $\begin{array}{c}\chi^{2}=0.08, \mathrm{df}=1 \\
\mathrm{p}=0.78\end{array}$ & $7 / 10$ & $1 / 2$ & $\begin{array}{c}\chi^{2}=0.15, \mathrm{df}=1, \\
\mathrm{p}=0.70\end{array}$ \\
\hline \multicolumn{7}{|l|}{ Antidepressants } \\
\hline Age & $53.79 \pm 18.43$ & $53.89 \pm 17.70$ & $\begin{array}{c}\mathrm{t}=-0.03, \mathrm{CI}=-7.56-7.37 \\
\mathrm{p}=0.98\end{array}$ & $53.54 \pm 18.80$ & $54.24 \pm 17.20$ & $\begin{array}{c}\mathrm{t}=-0.19, \mathrm{CI}=-7.87-6.46, \\
\mathrm{p}=0.85\end{array}$ \\
\hline Gender (F/M) & $42 / 25$ & $28 / 8$ & $\begin{array}{c}\chi^{2}=1.81, \mathrm{df}=1 \\
\mathrm{p}=0.18\end{array}$ & $39 / 23$ & $31 / 10$ & $\begin{array}{c}\chi^{2}=1.29, \mathrm{df}=1 \\
\mathrm{p}=0.26\end{array}$ \\
\hline $\begin{array}{l}\text { Baseline severity } \\
\text { (HAM-D) }\end{array}$ & $18.46 \pm 4.76$ & $17.39 \pm 4.04$ & $\begin{array}{c}\mathrm{t}=1.21, \mathrm{CI}=-0.70-2.84 \\
\mathrm{p}=0.23\end{array}$ & $17.74 \pm 4.98$ & $18.61 \pm 3.74$ & $\begin{array}{c}\mathrm{t}=-0.01, \mathrm{CI}=-2.58-0.84, \\
\mathrm{p}=0.32\end{array}$ \\
\hline $\begin{array}{l}\text { Personality disorder } \\
(\text { yes/no)* }\end{array}$ & $14 / 28$ & $11 / 14$ & $\begin{array}{c}\chi^{2}=0.37, d f=1 \\
p=0.54\end{array}$ & $14 / 26$ & $11 / 16$ & $\begin{array}{c}\chi^{2}=0.04, d f=1 \\
p=0.83\end{array}$ \\
\hline
\end{tabular}

*available for only 2 centers (Bologna and Torino). CI: 95\% confidence interval, HDRS: Hamilton Depression Rating Scale 21-items, IPC: interpersonal counseling, Stat: statistics 
tured psychological intervention, IPC, versus the more widely used antidepressant drug treatment, together with the effect of five serotonin-related polymorphisms on clinical outcomes in both treatment groups as well as in the whole sample. No differences in response, remission rates and percent of improvement at week 8 were found between the two treatment arms (Table 2), also adjusting for age, baseline severity and center. Our findings support the efficacy of IPC in the treatment of mild-moderate MDD, suggesting it is a useful alternative to antidepressants. The choice of IPC may be particularly useful in patients with higher risk of drug-related adverse events, like the elderly (because of polypharmacy and chronic diseases), pregnant women and in post-partum MDD, as confirmed by the marginally higher number of discontinua-

Table 4. Response and remission rates at week 8 for each genotype and treatment group

\begin{tabular}{|c|c|c|c|c|c|c|c|c|}
\hline \multirow[b]{2}{*}{ COMT rs4680 } & \multicolumn{4}{|c|}{$\operatorname{ICP}(\mathrm{N}=40)$} & \multicolumn{4}{|c|}{ Antidepressants $(\mathrm{N}=102)$} \\
\hline & AA & AG & GG & Stat & AA & AG & GG & Stat \\
\hline \multicolumn{9}{|l|}{ Response } \\
\hline Yes & $5(20)$ & $16(64)$ & $4(16)$ & \multirow{2}{*}{$\begin{array}{c}\chi^{2}=3.07, \mathrm{df}=2, \\
p=0.21\end{array}$} & $12(18.18)$ & $38(57.58)$ & $16(24.24)$ & \multirow{2}{*}{$\begin{array}{c}\chi^{2}=0.98, d f=2 \\
p=0.61\end{array}$} \\
\hline No & $5(33.33)$ & $10(66.67)$ & $0(0)$ & & $6(16.67)$ & $18(50.00)$ & $12(33.33)$ & \\
\hline \multicolumn{9}{|l|}{ Remission } \\
\hline Yes & $6(21.43)$ & $19(67.86)$ & $3(10.71)$ & \multirow{2}{*}{$\begin{array}{c}\chi^{2}=0.64, d f=2 \\
p=0.73\end{array}$} & $12(19.67)$ & $36(59.02)$ & $13(21.31)$ & \multirow{2}{*}{$\begin{array}{c}\chi^{2}=2.90, \mathrm{df}=2 \\
\mathrm{p}=0.23\end{array}$} \\
\hline No & $4(33.33)$ & $7(58.33)$ & $1(8.33)$ & & $6(14.63)$ & $20(48.78)$ & $15(31.71)$ & \\
\hline HTR1A rs6295 & $\mathrm{CC}$ & CG & GG & & $\mathrm{CC}$ & CG & GG & \\
\hline \multicolumn{9}{|l|}{ Response } \\
\hline Yes & $7(28.00)$ & $13(52.00)$ & $5(20.00)$ & \multirow{2}{*}{$\begin{array}{c}\chi^{2}=0.01, d f=2 \\
p=0.9954\end{array}$} & $13(19.70)$ & $28(42.42)$ & $25(37.88)$ & \multirow{2}{*}{$\begin{array}{c}\chi^{2}=0.93, d f=2 \\
p=0.63\end{array}$} \\
\hline No & $4(23.53)$ & $8(47.06)$ & $3(17.65)$ & & $10(27.78)$ & $13(36.11)$ & $13(36.11)$ & \\
\hline \multicolumn{9}{|l|}{ Remission } \\
\hline Yes & $9(32.14)$ & $14(50.00)$ & $5(17.86)$ & \multirow{2}{*}{$\begin{array}{c}\chi^{2}=1.06, \mathrm{df}=2, \\
p=0.59\end{array}$} & $13(21.31)$ & $24(39.34)$ & $24(39.34)$ & \multirow{2}{*}{$\begin{array}{c}\chi^{2}=0.31, d f=2 \\
p=0.86\end{array}$} \\
\hline No & $2(16.67)$ & $7(58.33)$ & $3(25.00)$ & & $10(24.39)$ & $17(41.46)$ & $14(34.15)$ & \\
\hline HTR2A rs2224721 & $\mathrm{AA}$ & $\mathrm{CA}$ & $\mathrm{CC}$ & & $\mathrm{AA}$ & $\mathrm{CA}$ & $\mathrm{CC}$ & \\
\hline \multicolumn{9}{|l|}{ Response } \\
\hline Yes & $1(4.00)$ & $10(40.00)$ & $14(56.00)$ & \multirow{2}{*}{$\begin{array}{c}\chi^{2}=0.39, \mathrm{df}=2, \\
\mathrm{p}=0.82\end{array}$} & $6(9.09)$ & $20(30.30)$ & $40(60.61)$ & \multirow{2}{*}{$\begin{array}{c}\chi^{2}=3.91, d f=2 \\
p=0.14\end{array}$} \\
\hline No & $1(6.67)$ & $7(46.67)$ & $7(46.67)$ & & $2(5.56)$ & $18(50.00)$ & $16(44.44)$ & \\
\hline \multicolumn{9}{|l|}{ Remission } \\
\hline Yes & $2(7.14)$ & $10(35.71)$ & $16(57.14)$ & \multirow{2}{*}{$\begin{array}{c}\chi^{2}=2.25, \mathrm{df}=2, \\
p=0.32\end{array}$} & $5(8.20)$ & $22(36.01)$ & $34(55.74)$ & \multirow{2}{*}{$\begin{array}{c}\chi^{2}=0.10, \mathrm{df}=2, \\
\mathrm{p}=0.95\end{array}$} \\
\hline No & $0(0)$ & $7(58.33)$ & $5(41.67)$ & & $3(7.32)$ & $16(39.02)$ & $22(53.66)$ & \\
\hline HTR2A rs7997012 & $\mathrm{AA}$ & GA & GG & & AA & GA & GG & \\
\hline \multicolumn{9}{|l|}{ Response } \\
\hline Yes & $1(4.00)$ & $10(40.00)$ & $14(56.00)$ & \multirow{2}{*}{$\begin{array}{c}\chi^{2}=2.42, \mathrm{df}=2, \\
\mathrm{p}=0.30\end{array}$} & $6(9.09)$ & $29(43.94)$ & $31(46.97)$ & \multirow{2}{*}{$\begin{array}{c}\chi^{2}=2.33, \mathrm{df}=2, \\
\mathrm{p}=0.31\end{array}$} \\
\hline No & $2(13.33)$ & $3(17.65)$ & $10(66.67)$ & & $7(19.44)$ & $15(41.67)$ & $14(38.89)$ & \\
\hline \multicolumn{9}{|l|}{ Remission } \\
\hline Yes & $1(3.57)$ & $11(39.29)$ & $16(57.14)$ & \multirow{2}{*}{$\begin{array}{c}\chi^{2}=3.37, d f=2, \\
p=0.19\end{array}$} & $5(8.20)$ & $28(45.90)$ & $28(45.90)$ & \multirow{2}{*}{$\begin{array}{c}\chi^{2}=2.84, d f=2, \\
p=0.24\end{array}$} \\
\hline No & $2(16.67)$ & $2(16.67)$ & $8(66.67)$ & & $8(19.51)$ & $16(39.02)$ & $17(41.46)$ & \\
\hline SLC6A4 rs4251417 & $\mathrm{AA}$ & GA & GG & & $\mathrm{AA}$ & $\mathrm{GA}$ & GG & \\
\hline Response & & & & & & & & \\
\hline Yes & $1(4.00)$ & $7(28.00)$ & $17(68.00)$ & $\chi^{2}=0.64, \mathrm{df}=2$, & $1(1.54)$ & $17(26.15)$ & $47(72.31)$ & $\chi^{2}=2.73, \mathrm{df}=2$, \\
\hline No & $0(0)$ & $4(26.67)$ & $11(73.33)$ & $\mathrm{p}=0.72$ & $0(0)$ & $5(13.89)$ & $31(86.11)$ & $\mathrm{p}=0.26$ \\
\hline Remission & & & & & & & & \\
\hline Yes & $1(3.57)$ & $9(32.14)$ & $18(64.29)$ & $\chi^{2}=1.59, \mathrm{df}=2$, & $1(1.68)$ & $15(25.00)$ & $44(73.33)$ & $\chi^{2}=1.67, \mathrm{df}=2$, \\
\hline No & $0(0)$ & $2(16.67)$ & $10(83.33)$ & $\mathrm{p}=0.45$ & $0(0)$ & $7(17.07)$ & $34(82.93)$ & $\mathrm{p}=0.43$ \\
\hline
\end{tabular}

IPC: interpersonal counseling, COMT: catechol-O-methyltransferase, HTR1A: 5-hydroxytryptamine (serotonin) receptor 1A, HTR2A: 5-hydroxytryptamine (serotonin) receptor 2A, SLC6A4: solute carrier family 6 (neurotransmitter transporter, serotonin), member 4 
tions in the antidepressant group. Only in the IPC arm, responders showed higher HDRS scores at baseline, while the opposite picture was seen for remitters (Table 3). Also previous studies reported contradictory results about the association between baseline severity score and antidepressant treatment outcome, which do not allow a clear interpretation. ${ }^{52}$ Anyway, baseline severity scores per se are probably not a pre- dictor of clinical outcome, but possibly only in particular groups of patients (e.g., presence of dysfunctional personality traits $^{53}$ ) or depending from the type of treatment. ${ }^{54}$

None of the investigated serotonin-related variants was found associated with clinical outcomes, either in the antidepressant or in the IPC group (Table 4 and 5) also adjusting results for confounding variables (site of recruitment and base-

Table 5. Response and remission rates at week 8 for each allele and treatment group

\begin{tabular}{|c|c|c|c|c|c|c|}
\hline \multirow[b]{2}{*}{ COMT rs4680 } & \multicolumn{3}{|c|}{$\operatorname{ICP}(\mathrm{N}=40)$} & \multicolumn{3}{|c|}{ Antidepressants $(\mathrm{N}=102)$} \\
\hline & $\mathrm{A}$ & G & Stat & A & G & Stat \\
\hline \multicolumn{7}{|l|}{ Response } \\
\hline Yes & $26(52.00)$ & $24(48.00)$ & \multirow{2}{*}{$\begin{array}{c}\chi^{2}=1.10, \mathrm{df}=1, \\
\mathrm{p}=0.29\end{array}$} & $62(46.97)$ & $70(53.03)$ & \multirow{2}{*}{$\begin{array}{c}\chi^{2}=0.34, \mathrm{df}=1, \\
\mathrm{p}=0.56\end{array}$} \\
\hline No & $20(66.67)$ & $10(33.33)$ & & $30(41.67)$ & $42(58.33)$ & \\
\hline \multicolumn{7}{|l|}{ Remission } \\
\hline Yes & $31(55.36)$ & $25(44.64)$ & \multirow{2}{*}{$\begin{array}{c}\chi^{2}=0.12, \mathrm{df}=1, \\
\mathrm{p}=0.73\end{array}$} & $60(49.18)$ & $62(50.82)$ & \multirow{2}{*}{$\begin{array}{c}\chi^{2}=1.65, d f=1, \\
p=0.20\end{array}$} \\
\hline No & $15(62.50)$ & $9(37.50)$ & & $32(39.02)$ & $50(60.98)$ & \\
\hline HTR1A rs6295 & $\mathrm{C}$ & G & & $\mathrm{C}$ & G & \\
\hline \multicolumn{7}{|l|}{ Response } \\
\hline Yes & $27(54.00)$ & $23(46.00)$ & \multirow{2}{*}{$\begin{array}{c}\chi^{2}=0.03, \mathrm{df}=1, \\
\mathrm{p}=0.86\end{array}$} & $54(40.90)$ & $78(59.10)$ & \multirow{2}{*}{$\begin{array}{c}\chi^{2}=0.28, \mathrm{df}=1 \\
\mathrm{p}=0.60\end{array}$} \\
\hline No & $16(53.33)$ & $14(46.67)$ & & $33(45.83)$ & $39(54.17)$ & \\
\hline \multicolumn{7}{|l|}{ Remission } \\
\hline Yes & $32(57.14)$ & $24(42.86)$ & \multirow{2}{*}{$\begin{array}{c}\chi^{2}=0.47, \mathrm{df}=1, \\
\mathrm{p}=0.49\end{array}$} & $50(40.98)$ & $72(59.02)$ & \multirow{2}{*}{$\begin{array}{c}\chi^{2}=0.20, d f=1 \\
p=0.66\end{array}$} \\
\hline No & $11(45.83)$ & $13(54.17)$ & & $37(45.12)$ & $45(54.88)$ & \\
\hline HTR2A rs2224721 & $\mathrm{A}$ & $\mathrm{C}$ & & $\mathrm{A}$ & $\mathrm{C}$ & \\
\hline \multicolumn{7}{|l|}{ Response } \\
\hline Yes & $12(24.00)$ & $38(76.00)$ & \multirow{2}{*}{$\begin{array}{c}\chi^{2}=0.11, \mathrm{df}=1, \\
\mathrm{p}=0.74\end{array}$} & $32(24.24)$ & $100(75.76)$ & \multirow{2}{*}{$\begin{array}{c}\chi^{2}=0.66, d f=1 \\
p=0.42\end{array}$} \\
\hline No & $9(30.00)$ & $21(70.00)$ & & $22(30.56)$ & $50(69.44)$ & \\
\hline \multicolumn{7}{|l|}{ Remission } \\
\hline Yes & $14(25.00)$ & $42(75.00)$ & \multirow{2}{*}{$\begin{array}{c}\chi^{2}=0.01, \mathrm{df}=1, \\
\mathrm{p}=0.91\end{array}$} & $32(26.23)$ & $90(73.77)$ & \multirow{2}{*}{$\begin{array}{c}\chi^{2}=0.004, d f=1 \\
p=0.95\end{array}$} \\
\hline No & $7(29.17)$ & $17(70.83)$ & & $22(26.83)$ & $60(73.17)$ & \\
\hline HTR2A rs7997012 & $\mathrm{A}$ & G & & $\mathrm{A}$ & G & \\
\hline \multicolumn{7}{|l|}{ Response } \\
\hline Yes & $12(24.00)$ & $38(76.00)$ & \multirow{2}{*}{$\begin{array}{c}\chi^{2}=0.04, \mathrm{df}=1, \\
\mathrm{p}=0.84\end{array}$} & $41(31.06)$ & $91(68.94)$ & \multirow{2}{*}{$\begin{array}{c}\chi^{2}=1.37, \mathrm{df}=1 \\
\mathrm{p}=0.24\end{array}$} \\
\hline No & $7(23.33)$ & $23(76.67)$ & & $29(40.28)$ & $43(59.72)$ & \\
\hline \multicolumn{7}{|l|}{ Remission } \\
\hline Yes & $13(23.21)$ & $43(76.79)$ & \multirow{2}{*}{$\begin{array}{c}\chi^{2}=0.01, \mathrm{df}=1, \\
\mathrm{p}=0.91\end{array}$} & $38(31.15)$ & $84(68.85)$ & \multirow{2}{*}{$\begin{array}{c}\chi^{2}=1.02, d f=1 \\
p=0.31\end{array}$} \\
\hline No & $6(25.00)$ & $18(75.00)$ & & $32(39.02)$ & $50(60.98)$ & \\
\hline SLC6A4 rs4251417 & A & G & & A & G & \\
\hline \multicolumn{7}{|l|}{ Response } \\
\hline Yes & $9(18.00)$ & $41(82.00)$ & $\chi^{2}=0.05, \mathrm{df}=1$, & $19(14.62)$ & $111(85.38)$ & $\chi^{2}=1.92, \mathrm{df}=1$, \\
\hline No & $4(13.33)$ & $26(86.67)$ & $\mathrm{p}=0.81$ & $5(6.94)$ & $67(93.06)$ & $\mathrm{p}=0.17$ \\
\hline Remission & & & & & & \\
\hline Yes & $11(19.64)$ & $45(80.36)$ & $\chi^{2}=0.86, \mathrm{df}=1$, & $17(14.17)$ & $103(85.83)$ & $\chi^{2}=0.99, \mathrm{df}=1$, \\
\hline No & $2(8.33)$ & $22(91.67)$ & $\mathrm{p}=0.35$ & $7(8.54)$ & $75(91.46)$ & $\mathrm{p}=0.32$ \\
\hline
\end{tabular}

IPC: interpersonal counseling, COMT: catechol-O-methyltransferase, HTR1A: 5-hydroxytryptamine (serotonin) receptor 1A, HTR2A: 5-hydroxytryptamine (serotonin) receptor 2A, SLC6A4: solute carrier family 6 (neurotransmitter transporter, serotonin), member 4 
line severity-IPC group). The polymorphisms of interest were investigated also in the whole sample, since similar mechanisms of action are supposed to lay behind the clinical efficacy of both antidepressant drugs and psychotherapy ${ }^{44,45}$ In the whole sample a trend of lower remission was found in subjects carrying the AA genotype of rs7997012, as well as lower percent HDRS improvement at week 8 was observed in this group ( $38.74 \pm 33.89$ vs. $58.13 \pm 27.91$ of the GA and $55.67 \pm$ 27.33 of the GG genotypes).

The studied polymorphisms were carefully selected in accordance with the known biological function and previous pharmacogenetic findings. The role of COMT rs4680 and HTR1A rs6295 has been repeatedly studied, but with inconsistent results, particularly in regard to the identification of the risk allele. ${ }^{6}$ On the other hand, HTR2A rs2224721 and SLC6A4 rs4251417 are new candidates, since the former was one of the best pharmacogenetic findings of the GENDEP study ${ }^{14}$ but confirmations are lacking, while the latter has not been studied yet as predictor of antidepressant efficacy despite of its key position. Despite our overall negative findings, a trend of association with HTR2A variants was detected, supporting the quite replicated evidence which suggest a role of the gene in antidepressant effect. ${ }^{10-12}$ Indeed, HTR2A rs7997012 A allele was a confirmed predictor of citalopram response in the STAR*D study, ${ }^{10,11}$ while in the GENDEP study an association in the opposite direction was reported, ${ }^{12}$ in line with our results; finally, some smaller studies reported negative findings. ${ }^{13-16}$ The other interesting result involving HTR2A is a detrimental effect of rs2224721 A allele only in males, who showed a lower HDRS improvement compared to males carrying the $\mathrm{C}$ allele. The finding supports the hypothesis of a gender-stratification effect affecting the association between genetic variants and antidepressant outcome, as several lines of evidence previously suggested. ${ }^{55}$

Nevertheless, the overall negative findings provided by the present study further suggest that the role of these polymorphisms in antidepressant efficacy is probably modest, i.e., the explained variance in response is probably low considering only one polymorphism at a time. For example, rs2224721 explained only about the $1.1 \%$ of the variance in response to escitalopram in the GENDEP study, despite it was one of the SNPs with higher evidence of association ${ }^{14}$ and in our study we could not detect explained variances lower than $2.2 \%$. Indeed, the small sample size is the major limitation of the present study, and also the multicenter nature may introduce biases, but we used all standard methods to avoid center effects, and consequently no center stratification effect was observed. The lack of a combined treatment arm may be seen as a limitation, but the available evidence suggest no clear benefit of combined treatment over monotherapy in mild-moderate
$\mathrm{MDD},{ }^{4}$ thus no further useful information could be derived from this analysis. As for strengths, despite the relative small sample size, the present study is the first to investigate the role of serotonin-related genetic variants in both psychotherapy and antidepressant treated MDD patients. Serotoninergic genes indeed are a priori optimal candidates for both types of treatment, since the emerging evidence of similar underlying neurobiological basis. ${ }^{44,45,56}$ Some differences in baseline clinical characteristics were observed between the antidepressant and IPC treated groups (Table 2), this also explains the apparently opposite effects of baseline severity on outcome for IPC, but all regression models comparing the two groups were adjusted for the effect of these confounding variables.

Our results suggest no major role of rs7997012 and rs2224 721 (HTR2A), rs6295 (HTR1A), rs4251417 (SLC6A4) and rs4680 (COMT) in both IPC and antidepressant efficacy. Considering both treatment arms, a trend of worse outcome was detected in carriers of the rs7997012 AA genotype (HTR2A gene), while in all treatment groups as well as the combined sample males carrying the A allele of rs2224721 (HTR2A gene) showed a trend of worse outcome, that was not observed in females. The present study also concluded that IPC, a brief structured psychological intervention, shows similar efficacy to antidepressant drugs in mild-moderate MDD, confirming its clinical usefulness when pharmacological treatments are contraindicated, refused or not tolerated.

\section{Acknowledgments}

The study was sponsored by MIUR (2008XWR4SB).

\section{REFERENCES}

1. Alonso J, Angermeyer MC, Bernert S, Bruffaerts R, Brugha TS, Bryson $\mathrm{H}$, et al. Disability and quality of life impact of mental disorders in Europe: results from the European Study of the Epidemiology of Mental Disorders (ESEMeD) project. Acta Psychiatr Scand Suppl 2004;(420): 38-46.

2. Trivedi MH, Rush AJ, Wisniewski SR, Nierenberg AA, Warden D, Ritz L, et al. Evaluation of outcomes with citalopram for depression using measurement-based care in STAR*D: implications for clinical practice. Am J Psychiatry 2006;163:28-40.

3. Unutzer J, Park M. Strategies to improve the management of depression in primary care. Prim Care 2012;39:415-431.

4. Busch FN, Sandberg LS. Combined treatment of depression. Psychiatr Clin North Am 2012;35:165-179.

5. Frank E, Cassano GB, Rucci P, Thompson WK, Kraemer HC, Fagiolini A, et al. Predictors and moderators of time to remission of major depression with interpersonal psychotherapy and SSRI pharmacotherapy. Psychol Med 2011;41:151-162.

6. Porcelli S, Drago A, Fabbri C, Gibiino S, Calati R, Serretti A. Pharmacogenetics of antidepressant response. J Psychiatry Neurosci 2011;36: 87-113.

7. Ban TA. Pharmacotherapy of depression: a historical analysis. J Neural Transm 2001;108:707-716.

8. Burnet PW, Eastwood SL, Lacey K, Harrison PJ. The distribution of 5-HT1A and 5-HT2A receptor mRNA in human brain. Brain Res 1995; 676:157-168. 
9. Landen M, Thase ME. A model to explain the therapeutic effects of serotonin reuptake inhibitors: the role of 5-HT2 receptors. Psychopharmacol Bull 2006;39:147-166.

10. McMahon FJ, Buervenich S, Charney D, Lipsky R, Rush AJ, Wilson AF, et al. Variation in the gene encoding the serotonin $2 \mathrm{~A}$ receptor is associated with outcome of antidepressant treatment. Am J Hum Genet 2006;78:804-814.

11. Peters EJ, Slager SL, Jenkins GD, Reinalda MS, Garriock HA, Shyn SI, et al. Resequencing of serotonin-related genes and association of tagging SNPs to citalopram response. Pharmacogenet Genomics 2009;19: $1-10$.

12. Horstmann S, Lucae S, Menke A, Hennings JM, Ising M, Roeske D, et al. Polymorphisms in GRIK4, HTR2A, and FKBP5 show interactive effects in predicting remission to antidepressant treatment. Neuropsychopharmacology 2010;35:727-740.

13. Perlis RH, Fijal B, Adams DH, Sutton VK, Trivedi MH, Houston JP. Variation in catechol-O-methyltransferase is associated with duloxetine response in a clinical trial for major depressive disorder. Biol Psychiatry 2009;65:785-791.

14. Uher R, Huezo-Diaz P, Perroud N, Smith R, Rietschel M, Mors O, et al. Genetic predictors of response to antidepressants in the GENDEP project. Pharmacogenomics J 2009;9:225-233.

15. Kishi T, Yoshimura R, Kitajima T, Okochi T, Okumura T, Tsunoka T, et al. HTR2A is associated with SSRI response in major depressive disorder in a Japanese cohort. Neuromolecular Med 2010;12:237-242.

16. Illi A, Setala-Soikkeli E, Viikki M, Poutanen O, Huhtala H, Mononen N, et al. 5-HTR1A, 5-HTR2A, 5-HTR6, TPH1 and TPH2 polymorphisms and major depression. Neuroreport 2009;20:1125-1128.

17. Lucae S, Ising M, Horstmann S, Baune BT, Arolt V, Muller-Myhsok B, et al. HTR2A gene variation is involved in antidepressant treatment response. Eur Neuropsychopharmacol 2010;20:65-68.

18. Viikki M, Huuhka K, Leinonen E, Illi A, Setala-Soikkeli E, Huuhka M, et al. Interaction between two HTR2A polymorphisms and gender is associated with treatment response in MDD. Neurosci Lett 2011;501: 20-24.

19. McAuley EZ, Fullerton JM, Blair IP, Donald JA, Mitchell PB, Schofield $\mathrm{PR}$. Association between the serotonin 2A receptor gene and bipolar affective disorder in an Australian cohort. Psychiatr Genet 2009;19:244252.

20. Albert PR, Lemonde S. 5-HT1A receptors, gene repression, and depression: guilt by association. Neuroscientist 2004;10:575-593.

21. Lemonde S, Turecki G, Bakish D, Du L, Hrdina P, Bown C, et al. Impaired repression at a 5 -hydroxytryptamine $1 \mathrm{~A}$ receptor gene polimorphism associated with major depression and suicide. J Neurosci 2003; 23:8788-8799.

22. Arias B, Catalan R, Gasto C, Gutierrez B, Fananas L. Evidence for a combined genetic effect of the 5-HT(1A) receptor and serotonin transporter genes in the clinical outcome of major depressive patients treated with citalopram. J Psychopharmacol 2005;19:166-172.

23. Hong CJ, Chen TJ, Yu YW, Tsai SJ. Response to fluoxetine and serotonin 1A receptor (C-1019G) polymorphism in Taiwan Chinese major depressive disorder. Pharmacogenomics J 2006;6:27-33.

24. Kato M, Fukuda T, Wakeno M, Okugawa G, Takekita Y, Watanabe S, et al. Effect of 5-HT1A gene polymorphisms on antidepressant response in major depressive disorder. Am J Med Genet B Neuropsychiatr Genet 2009;150B:115-123.

25. Lemonde S, Du L, Bakish D, Hrdina P, Albert PR. Association of the C(-1019)G 5-HT1A functional promoter polymorphism with antidepressant response. Int J Neuropsychopharmacol 2004;7:501-506.

26. Parsey RV, Olvet DM, Oquendo MA, Huang YY, Ogden RT, Mann JJ. Higher 5-HT1A receptor binding potential during a major depressive episode predicts poor treatment response: preliminary data from a naturalistic study. Neuropsychopharmacology 2006;31:1745-1749.

27. Serretti A, Artioli P, Lorenzi C, Pirovano A, Tubazio V, Zanardi R. The C(-1019)G polymorphism of the 5-HT1A gene promoter and antide- pressant response in mood disorders: preliminary findings. Int J Neuropsychopharmacol 2004;7:453-460.

28. Villafuerte SM, Vallabhaneni K, Sliwerska E, McMahon FJ, Young EA, Burmeister M. SSRI response in depression may be influenced by SNPs in HTR1B and HTR1A. Psychiatr Genet 2009;19:281-291.

29. Levin GM, Bowles TM, Ehret MJ, Langaee T, Tan JY, Johnson JA, et al. Assessment of human serotonin $1 \mathrm{~A}$ receptor polymorphisms and SSRI responsiveness. Mol Diagn Ther 2007;11:155-160.

30. Lin E, Chen PS, Chang HH, Gean PW, Tsai HC, Yang YK, et al. Interaction of serotonin-related genes affects short-term antidepressant response in major depressive disorder. Prog Neuropsychopharmacol Biol Psychiatry 2009;33:1167-1172.

31. Noro M, Antonijevic I, Forray C, Kasper S, Kocabas NA, Lecrubier Y, et al. 5HT1A and 5HT2A receptor genes in treatment response phenotypes in major depressive disorder. Int Clin Psychopharmacol 2010; 25:228-231.

32. Peters EJ, Slager SL, McGrath PJ, Knowles JA, Hamilton SP. Investigation of serotonin-related genes in antidepressant response. Mol Psychiatry 2004;9:879-889.

33. Yu YW, Tsai SJ, Liou YJ, Hong CJ, Chen TJ. Association study of two serotonin $1 \mathrm{~A}$ receptor gene polymorphisms and fluoxetine treatment response in Chinese major depressive disorders. Eur Neuropsychopharmacol 2006;16:498-503.

34. Wray NR, James MR, Gordon SD, Dumenil T, Ryan L, Coventry WL, et al. Accurate, large-scale genotyping of 5HTTLPR and flanking single nucleotide polymorphisms in an association study of depression, anxiety, and personality measures. Biol Psychiatry 2009;66:468-476.

35. Weinshilboum RM, Otterness DM, Szumlanski CL. Methylation pharmacogenetics: catechol O-methyltransferase, thiopurine methyltransferase, and histamine N-methyltransferase. Annu Rev Pharmacol Toxicol 1999;39:19-52.

36. Arias B, Serretti A, Lorenzi C, Gasto C, Catalan R, Fananas L. Analysis of COMT gene (Val 158 Met polymorphism) in the clinical response to SSRIs in depressive patients of European origin. J Affect Disord 2006; 90:251-256.

37. Baune BT, Hohoff C, Berger K, Neumann A, Mortensen S, Roehrs T, et al. Association of the COMT val158met variant with antidepressant treatment response in major depression. Neuropsychopharmacology 2008;33:924-932.

38. Benedetti F, Colombo C, Pirovano A, Marino E, Smeraldi E. The catechol-O-methyltransferase $\mathrm{Val}(108 / 158)$ Met polymorphism affects antidepressant response to paroxetine in a naturalistic setting. Psychopharmacology (Berl) 2009;203:155-160.

39. Szegedi A, Rujescu D, Tadic A, Muller MJ, Kohnen R, Stassen HH, et al. The catechol-O-methyltransferase Val108/158Met polymorphism affects short-term treatment response to mirtazapine, but not to paroxetine in major depression. Pharmacogenomics J 2005;5:49-53.

40. Tsai SJ, Gau YT, Hong CJ, Liou YJ, Yu YW, Chen TJ. Sexually dimorphic effect of catechol-O-methyltransferase val158met polymorphism on clinical response to fluoxetine in major depressive patients. J Affect Disord 2009;113:183-187.

41. Yoshida K, Higuchi H, Takahashi H, Kamata M, Sato K, Inoue K, et al. Influence of the tyrosine hydroxylase val81met polymorphism and catechol-O-methyltransferase val158met polymorphism on the antidepressant effect of milnacipran. Hum Psychopharmacol 2008;23:121128.

42. Beck AR, B. Shaw, G. Emery. Cognitive Therapy of Depression. New York: Guildford Press; 1988.

43. Simons AD, Garfield SL, Murphy GE. The process of change in cognitive therapy and pharmacotherapy for depression. Changes in mood and cognition. Arch Gen Psychiatry 1984;41:45-51.

44. Lehto SM, Tolmunen T, Joensuu M, Saarinen PI, Valkonen-Korhonen $\mathrm{M}$, Vanninen $\mathrm{R}$, et al. Changes in midbrain serotonin transporter availability in atypically depressed subjects after one year of psychotherapy. Prog Neuropsychopharmacol Biol Psychiatry 2008;32:229-237. 
45. Linden DE. How psychotherapy changes the brain--the contribution of functional neuroimaging. Mol Psychiatry 2006;11:528-538.

46. Menchetti M, Bortolotti B, Rucci P, Scocco P, Bombi A, Berardi D, et al. Depression in primary care: interpersonal counseling vs selective serotonin reuptake inhibitors. The DEPICS Study. A multicenter randomized controlled trial. Rationale and design. BMC Psychiatry 2010;10:97.

47. Judd FK, Piterman L, Cockram AM, McCall L, Weissman MM. A comparative study of venlafaxine with a focused education and psychotherapy program versus venlafaxine alone in the treatment of depression in general practice. Hum Psychopharmacol 2001;16:423-428.

48. Neugebauer R, Kline J, Bleiberg K, Baxi L, Markowitz JC, Rosing M, et al. Preliminary open trial of interpersonal counseling for subsyndromal depression following miscarriage. Depress Anxiety 2007;24:219-222.

49. Holmes A, Hodgins G, Adey S, Menzel S, Danne P, Kossmann T, et al. Trial of interpersonal counselling after major physical trauma. Aust $\mathrm{N}$ Z J Psychiatry 2007;41:926-933.

50. Oranta O, Luutonen S, Salokangas RK, Vahlberg T, Leino-Kilpi H. The outcomes of interpersonal counselling on depressive symptoms and distress after myocardial infarction. Nord J Psychiatry 2010;64:78-86.
51. Weissman M. Interpersonal Counselling for Stress and Distress in Primary Care: A Treatment Manual. New York: Columbia University;1988.

52. Serretti A, Chiesa A, Calati R, Perna G, Bellodi L, De Ronchi D. Common genetic, clinical, demographic and psychosocial predictors of response to pharmacotherapy in mood and anxiety disorders. Int Clin Psychopharmacol 2009;24:1-18.

53. Meyers BS, Sirey JA, Bruce M, Hamilton M, Raue P, Friedman SJ, et al. Predictors of early recovery from major depression among persons admitted to community-based clinics: an observational study. Arch Gen Psychiatry 2002;59:729-735.

54. Kilts CD, Wade AG, Andersen HF, Schlaepfer TE. Baseline severity of depression predicts antidepressant drug response relative to escitalopram. Expert Opin Pharmacother 2009;10:927-936.

55. Pitychoutis PM, Zisaki A, Dalla C, Papadopoulou-Daifoti Z. Pharmacogenetic insights into depression and antidepressant response: does sex matter? Curr Pharm Des 2010;16:2214-2223.

56. Zaman R. Psychological treatments and brain plasticity. Psychiatr Danub 2010;22(Suppl 1):S6-S9. 